\title{
Environmental assessment of the exploitation of diesel engines powered by biofuels
}

Many factors, such as climate change and the associated risk of increasing the average temperature on the globe, energy security and the finishing of fossil fuel deposits have caused other renewable energy sources to be sought. Transport, as a branch of industry largely responsible for air pollution and greenhouse gas emissions in large cities, requires the necessary changes in the way vehicles are powered. Until now, the fuels available at petrol stations use admixtures of first generation biofuels, such as bioethanol, as a 5\% additive to motor gasolines and biodiesel (FAME) as a 7\% additive to diesel oil.

The article presents the idea of biorefinery installations, specifies the spectrum of substrates of the second and advanced generations, which may be a biorefinery input, including waste oils that can be used to produce hydrogenated HVO vegetable oils and other high-value products. The paper presents he existing biorefinery plant in Venice resulting from the transformation of a conventional oil refinery in which HVO fuel is produced. The article also presents the parameters of this new biofuel and compared them with the parameters of other fuels used to power self-ignition engines, such as FAME and diesel, along with discussing the prospects for HVO fuel development in Europe.

Key words: biorefineries, biofuels, green diesel, bioeconomy, hydrotreated vegetable oil

\section{Introduction}

Progressive climate change caused, among others greenhouse gas emissions (for example carbon dioxide) and drastically decreasing fossil fuel resources have forced our civilization to look for other, renewable energy carriers. One of the renewable energy sources is liquid biofuels, suitable for supplying internal combustion engines to replace conventional fuels like gasoline and diesel.

The currently existing first-generation biofuels for powering self-ignition internal combustion engines that are commonly used in Poland and in the world are, for example, biodiesel, which are fatty acid methyl esters (FAME) including methyl esters of rapeseed oil (RME) - of oilseeds obtained as a result of cold pressing processes, extraction and transesterification. These biofuels are produced from raw materials used in the food industry.

The concept of the next generation biofuels was created, among others based on unsatisfactory results of firstgeneration biofuels in terms of emissions and environmental impact, both in the combustion process in internal combustion engines and in the WtW cycle ("Well to Wheel"). This cycle is related to the entire biofuel production process, taking into account every stage of it, including the type of used raw material. Competing with the food market for raw material is also a disadvantage. Second generation liquid biofuels, among others for feeding self-ignition engines, they can be produced in installations called biorefineries, in which the feed is a widely understood waste biomass.

\section{Biofuels from biorefineries}

As a result of the review of the implementations and research works conducted in EU countries aimed at intensifying the processes of using RES, it turned out that these works are dispersed and do not bring the expected effect, both in the environmental aspect and in terms of energy conversion savings. For this reason, a vision of an industry based on raw materials of biological origin was created, to which waste substances from primary and secondary pro- cesses of using and processing biomass were also qualified as defined in Directive 2009/28/WE [1]. Implementation of this vision should lead to the transition towards the socalled "post-oil society" by clearly separating economic growth from resource depletion and environmental impact.

After the consultations carried out in the member states, the need to separate a new industrial branch defined as industry based on biological raw materials ("Bio-Based Industries"), which should strive to optimize land use and food safety through sustainable, efficient (effective) raw materials and to a large extent limiting the amount of waste generated, industrial processing of renewable raw materials into a wide range of products of biological origin, such as:

- advanced transport fuels,

- chemicals,

- materials,

- food and feed ingredients,

- energy [2].

As a result, "bio-industry", the main component of the EU economy called the "bioeconomy", will play a significant role in stimulating sustainable growth and enhancing Europe's competitiveness through the re-industrialization and revitalization of rural areas, ensuring that tens of thousands of jobs in research, development and production over the next decade [3].

One of the ways to mitigate the negative effects of local ecosystems influence is the conversion of biomass and organic waste to various products like chemicals, biomaterials and energy, to fully use the value of biomass, creating the so-called added value and minimizing the amount of generated or naturally produced waste substances. This integrated approach corresponds to the concept of biorefinery and is gaining more and more attention in many parts of the world.

Similar to conventional refineries where energy and chemical petroleum products are produced, biorefineries will produce many different industrial products from biomass. These products will be both LVHV (low-value and large-volume), such as transport fuels and large-volume 
chemicals and other materials, and HVLV (high-value and low-volume), such as specialty chemicals, such as cosmetics. In some types of installations, you can also produce food and feed for animals [4].

Biorefinery systems are nothing more than a type of open systems, where biomass, waste and energy are part of the input streams to the system. Inside the system there are a number of processes resulting in, among others exchanging the energy of the system with the environment in the form of heat and work. As output streams from biorefinery systems comes a number of products, such as fuels, chemicals both high-value, which are obtained in small quantities and low-value, obtained in large quantities, feed and food products, polymers and other materials, as well as energy produced in cogeneration or trigeneration (heat, electricity and cold) and process waste. It should be remembered that this waste is a waste only for a specific biorefinery process. For another biorefinery process, this waste may be a substrate [4]. The schema of biorefinery concept is presented in Fig. 1.

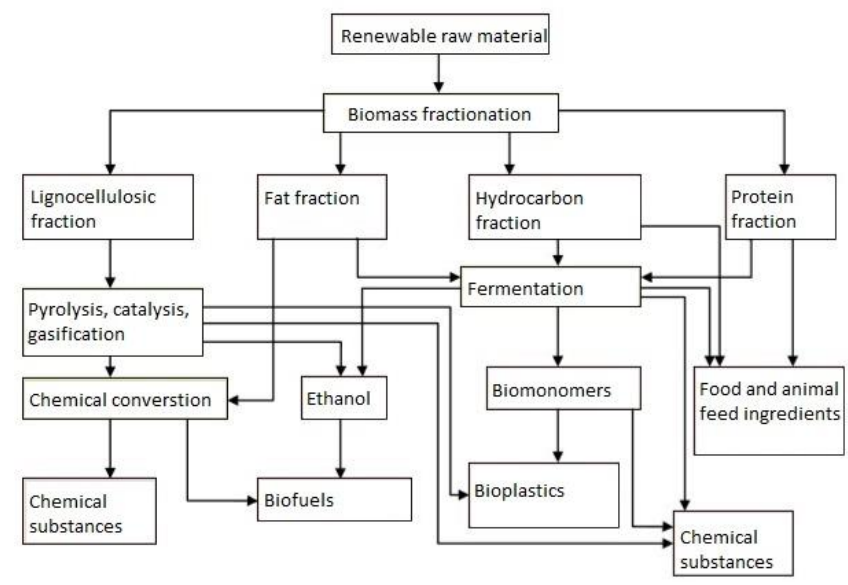

Fig. 1. Biorefinery concept schema [4]

By definition, biorefinery is a complex technological system that combines the processes of biomass conversion and further processing of products of this conversion into fuels and final chemicals, or for further processes. The biorefinery (Fig. 3) is therefore the equivalent of crude oil processing plants (Fig. 2), where the feedstock is crude oil or natural gas and other fossil energy resources. These resources are processed through petrochemical processes for various types of products, mainly fuels as well as electricity and heat as well as chemicals and various materials.

In the case of biorefineries, the substrate is organic materials such as wood, energy crops, grasses and organic waste, which are processed through biorefinery processes that largely coincide with refinery processes used in conventional oil refineries. The biorefinery products also include fuels and energy in cogeneration or trigeneration, chemicals and materials as well as food products and animal feed. The basic scheme of petrorefinery is presented in Fig. 2, while Fig. 3 presents the general ideological scheme of the biorefinery.

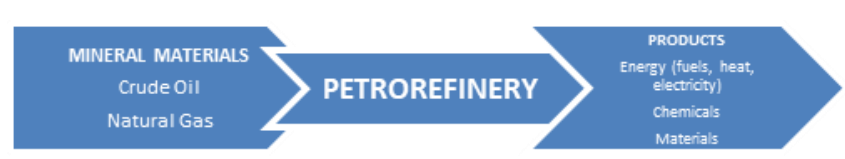

Fig. 2. Basic schema of classic refinery plant [4]

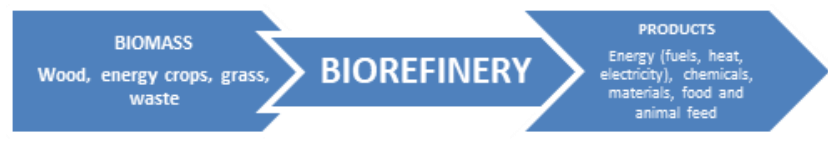

Fig. 3. The idea schema of biorefinery [4]

\section{Waste fats}

The processed vegetable fats and some animal fats can be collected both in gastronomy and in other industries. The processing of these fats is difficult due to the high content of free fatty acids. However, their price is very attractive, because it is only a fifth part of the price of fresh raw materials [5]. In one of the Austrian biofuel plants it is allowed to add up to $10 \%$ of used fats to the raw material, provided that the feedstock meets the quality requirements presented in Table 1.

Table 1. Quality requirements of raw material to the transesterification process in Austrian biofuels plant [5]

\begin{tabular}{|l|c|c|}
\hline \multicolumn{1}{|c|}{ Designation type } & Unit & Permissible amount \\
\hline Water content & $\% \mathrm{~m} / \mathrm{m}$ & 0.5 \\
\hline Free fatty acids content & $\% \mathrm{~m} / \mathrm{m}$ & 3.0 \\
\hline Iodine number & - & 115 \\
\hline Melting temperature & ${ }^{\circ} \mathrm{C}$ & 50 \\
\hline Sulphur content & $\% \mathrm{~m} / \mathrm{m}$ & 0.02 \\
\hline Phosphorus content & $\mathrm{ppm}$ & 10 \\
\hline Polymers content & $\% \mathrm{~m} / \mathrm{m}$ & 2 \\
\hline
\end{tabular}

Waste frying fats, expired food fats and oils stored for a long time in unfavorable conditions, i.e. with the access of air, humidity and sunlight, are characterized by different physicochemical properties in relation to fresh fats. As a result of the hydrolysis process, their acid number increases, oxygen processes change the peroxide number, and free radical reactions affect the density and viscosity of fat. Although these fats do not meet the requirements of the food industry and are treated as troublesome waste, they still contain significant amounts of unchanged triglycerides and can therefore be a very valuable raw material for the biofuel industry.

Initial purification of processed fats improves their color and odor, and also allows to reduce the density, viscosity, free fatty acid content and oxidized derivatives. Thanks to this, methanolysis reaction is easier, limiting the tendency to emulsion formation [6].

The obtained fatty acid methyl esters are characterized by better physicochemical properties, falling within the selected ranges given by the applicable fuel standard.

Diagram of an exemplary biorefinery installation producing a number of high-value products, such as various types of chemical substances, fatty acid methyl esters (FAME), hydrocarbon liquid, oleochemical products, chemicals, engine fuels and heat and electricity in cogeneration or trigeneration, using waste feed fats as a substrate are shown in Fig. 4. 


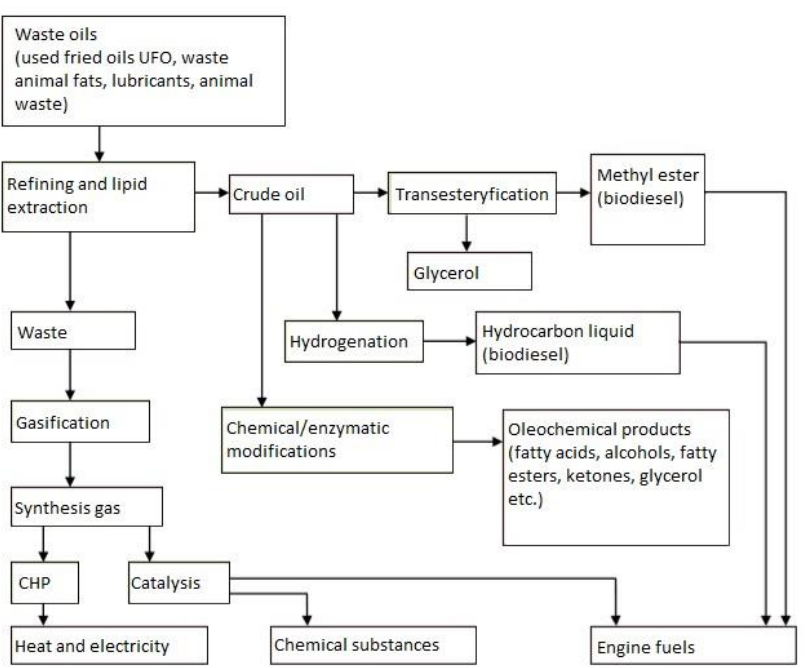

Fig. 4. Concept of biorefinery based on oily waste substances [4]

\section{Biorefinery in Venice}

An example of a biorefinery installation that uses waste fats from the Venetian restaurants and not only is a biorefinery from the Italian company Eni in Venice.

In 2014, the first conventional oil refinery in Europe was transformed into a biorefinery. In a difficult period for the European refining industry, the Venetian refinery found a way to re-use the catalytic hydrodesulfurization process.

Biorefinery produces biofuels with very high quality mainly green diesel (Green Diesel), but also "green petrol" (green naphtha), LPG gas and potentially even aviation fuel - all produced from biological raw materials. In this way, it helps to meet the requirements of the EU Renewable Energy Directive and ensure that conventional fuels produced in this biorefinery will have at least $10 \%$ share of components from renewable sources (biocomponents) by 2020 [7].

In this biorefinery, about $360,000 \mathrm{Mg}$ of vegetable oil is produced annually. The value is to increase to the value of $600,000 \mathrm{Mg}$ when the construction works, converting a conventional refinery into a biorefininery, will come to an end. Currently, palm oil is used for the production of biofuels and biocomponents due to its wide availability. This is due to the existing low availability of second and third generation raw material. However, these alternative fuels have already been tested and biorefinery is preparing to produce them in the near future [7].

Industrial research has confirmed which raw materials that do not compete with the food supply chain, such as used vegetable oils from around the country and animal fats, are suitable for biofuel processing. For this reason, it is advisable to talk about cooperation with public waste authorities in order to increase the collection of used oils from households for use it in biorefineries. In addition, waste products from the oily biomass refining process - i.e. "advanced" fuels, such as distilled fatty acids and glycerin should be re-used.

The process is based on innovative Ecofining technology, developed by Eni and tested in its laboratories. It produces very high-grade, sustainable biofuels without any of the disadvantages which affect other fuels currently on the market (fatty acid methyl esters - FAME). Consequently, it offers reduced particulate emissions and improved engine efficiency in line with current legislation and EU directives. The raw materials of biological origin used in the process can be divided into first generation feedstock (vegetable oils in competition with the food supply chain), second generation feedstock (waste animal fats, used cooking oils and agricultural waste) and third generation feedstock (oils from algae or waste). Ecofining technology can also be applied to second and third-generation feedstock, so anticipating any future changes in the regulations.

The Green Diesel fuel production process is based on innovative technology by Eni and tested in laboratories. Very high quality, balanced biofuels (advanced biofuels) are produced here, in which there are no disadvantages that currently exist on the market of biofuels, such as FAME. Consequently, these fuels provide reduced particulate emissions and improve engine performance, all in accordance with applicable EU regulations and directives.

\section{Green Diesel - biofuel and biocomponent}

The end product, known as hydrotreated vegetable oil (HVO) or green diesel, is a very high-quality diesel with excellent cetane levels (cetane number over 70, similar to top quality diesel obtained from GtL processes). It has a high heating value and is free from aromatic compounds and heteroatoms (sulphur, nitrogen or oxygen). The product is also immiscible with water and entirely compatible with diesel produced from petroleum (to which it can be added in a proportion of even up to $30 \%$ without any issues). Thus the obtained fuel respects the strictest regulations and offers the best performance for both engines and the environment [8].

The high calorific value of green diesel allows reduced consumption of plant feedstock (initially palm oil, certified to European standards) compared with traditional processes. In addition, in the near future, second and third-generation feedstock will also be able to be used, such as animal fats, used cooking oil, agricultural waste, oil from algae and other waste.

The main product of the HVO process is the, so called, Green Diesel. It has to be noted that the HVO plant is a type of biorefinery and thus allows for production of a wide range of products from biofuels to biochemicals. Except for Green Diesel, the HVO installation can be used to produce Green Jet Fuel while Green Naptha and Green LPG, together with propane, are the by-products of the production process [7].

The raw materials used in this process may have the same or lower quality in relation to the requirements in the production of classic biodiesel, whereas the product obtained in the HVO fuel production process has better properties. The main advantages of the fuel obtained in the HVO process are: high cetane number, high energy density and lack of oxygen in the molecule of the obtained fuel.

The key advantage of Green Diesel fuel is its CFPP level (cold filter plugging point), which can drop to $-20^{\circ} \mathrm{C}$ or even $-50^{\circ} \mathrm{C}$ (Table 2) regardless of the raw material used. This in turn makes the HVO suitable for use in cold winters, even in Scandinavian countries, as well as jet fuel [9]. 
Table 2. Comparison of properties of diesel oil, FAME fatty acid methyl esters and HVO diesel (Green Diesel) [9]

\begin{tabular}{|l|c|c|c|}
\hline \multicolumn{1}{|c|}{ Parameter } & $\begin{array}{c}\text { Diesel } \\
\text { oil }\end{array}$ & FAME & $\begin{array}{c}\text { HVO } \\
\text { diesel }\end{array}$ \\
\hline Bio Raw material [\%] & 0 & 100 & 100 \\
\hline Oxygen content [\%] & 0 & 11 & 0 \\
\hline Specific weight & 0.84 & 0.88 & 0.78 \\
\hline Sulphur content [ppm] & $<10$ & $<1$ & $<1$ \\
\hline Calorific value [MJ/kg] & 43 & 38 & 44 \\
\hline $\begin{array}{l}\text { Cold filter clogging tempera- } \\
\text { ture CFPP }\left[{ }^{\circ} \mathrm{C}\right]\end{array}$ & -15 & -14 & do -50 \\
\hline Cloud point [ $\left.{ }^{\circ} \mathrm{C}\right]$ & -5 & $-5-+15$ & do-20 \\
\hline Distillation range [ $\left.{ }^{\circ} \mathrm{C}\right]$ & $200-350$ & $340-355$ & $200-320$ \\
\hline $\begin{array}{l}\text { The contribution of polycyclic } \\
\text { compounds [\%] }\end{array}$ & 11 & 0 & 0 \\
\hline $\begin{array}{l}\text { Emissions of nitrogen oxides } \\
\text { NO }\end{array}$ & Standard & $+10 \%$ & $-10 \%$ \\
\hline Cetane number & 51 & $50-65$ & $70-90$ \\
\hline Oxidation stability & Standard & Poor & Excellent \\
\hline
\end{tabular}

Research and comparative analysis of other fuels sold in Italy confirmed the excellent properties of the Green Diesel additive. Due to the fact that $15 \%$ of solid fuel is renewable, this fuel significantly reduces emissions, reducing the number of unburned hydrocarbons and carbon monoxide by up to $40 \%$. In addition, a more durable production cycle helps reduce $\mathrm{CO}_{2}$ emissions by an average of 5\% [8]. Cold starting is easier and engine noise is reduced due to the high cetane ratio, compared to the standard minimum of 51 (Table 2 and Table 3).

Table 3. Comparison of properties of classic biodiesel and Green Diesel fuel (HVO) [10]

\begin{tabular}{|l|l|}
\hline \multicolumn{1}{|c|}{ Biodiesel } & \multicolumn{1}{c|}{ Green Diesel HVO } \\
\hline Poor chemical stability & $\begin{array}{l}\text { Excellent chemical stability and } \\
\text { excellent compatibility with } \\
\text { diesel }\end{array}$ \\
\hline $\begin{array}{l}\text { Variable quality depending on the } \\
\text { raw material used }\end{array}$ & $\begin{array}{l}\text { Constant quality regardless of } \\
\text { the raw material used }\end{array}$ \\
\hline $\begin{array}{l}\text { High probability of bacterial con- } \\
\text { tamination and resulting filter } \\
\text { installation }\end{array}$ & $\begin{array}{l}\text { Waterproof and able to avoid } \\
\text { bacterial contamination }\end{array}$ \\
\hline Low calorific value & $\begin{array}{l}\text { High calorific value and high } \\
\text { cetane number }\end{array}$ \\
\hline $\begin{array}{l}\text { Causes the dilution of the lubricat- } \\
\text { ing oil }\end{array}$ & $\begin{array}{l}\text { It does not dilute the oil, its } \\
\text { distillation properties are } \\
\text { similar to diesel oil }\end{array}$ \\
\hline $\begin{array}{l}\text { Limiting the additive in diesel to } \\
7 \% \text { (the „blend wall”) }\end{array}$ & $\begin{array}{l}\text { It can be mixed with diesel oil } \\
\text { in an unlimited way. It can also } \\
\text { act as 100\% biofuel. }\end{array}$ \\
\hline
\end{tabular}

\section{Green Diesel development predictions in Europe and in the World}

In connection with the forecasted increase in the demand for biodiesel in the RED II by $35 \%$ by 2030 , the expansion of the range of raw materials used for the production of renewable fuels used in self-ignition engines and the necessity of systematically increasing the share of advanced biofuels, it is expected that the demand for Green Diesel (HVO) will grow steadily.

It is estimated (Fig. 5) that by 2025 , HVO fuel production will increase twice on the European scale and will be trippled on a global scale in relation to the base year 2018, when HVO fuel production accounted for $17 \%$ of total biodiesel production (data do not concern installations producing $\mathrm{HVO}$ as a result of the co-hydrogenation process).

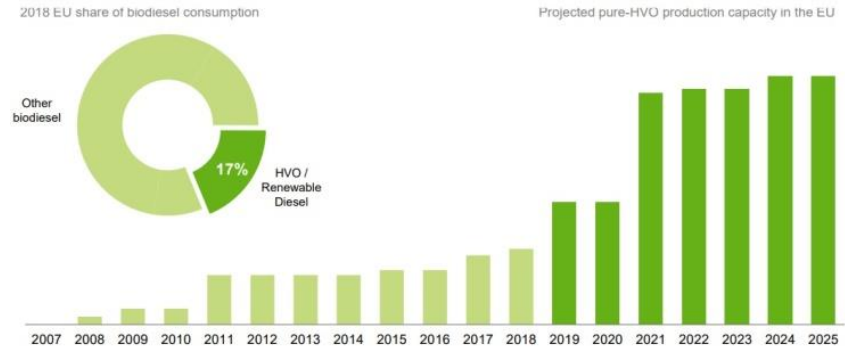

Fig. 5. Production capacity of HVO diesel in Europe [11]

HVO fuel is already known, manufactured and used in some European countries. These countries chose the Green Diesel fuel because of its favorable properties such as low freezing temperature, and also because of the possibility of exceeding the so-called "blend wall", meaning the threshold for the maximum amount of biodiesel that can be mixed with diesel. The concept of "blend wall" stands for the quality specifications of fuels issued by engine manufacturers.

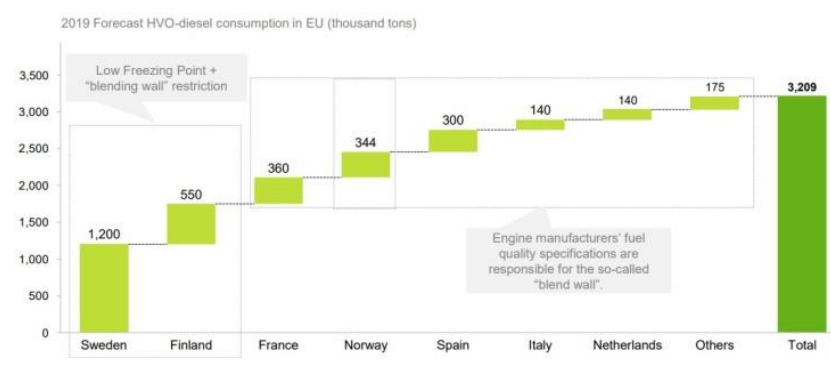

Fig. 6. Forecast of HVO fuel consumption in European countries [11]

It is forecasted that in 2019, the consumption of HVO fuel in European countries will reach a total of 3,209,000 $\mathrm{Mg}$, with Sweden, Finland, France, Norway and Spain being the largest consumers of this fuel (Fig. 6).

\section{Conclusions}

The Green Diesel fuel produced in the biorefinery in Venice can be blended with diesel oil, making up $15 \%$ of the mixture, and in this form it can be used in existing selfignition engines. This is possible due to a number of good engine properties of this biofuel. This mixture maintains the efficiency of the engine at the level of efficiency of the engine powered by conventional diesel fuel, while it is also responsible for a $4 \%$ reduction in fuel consumption compared to diesel with 5\% FAME addition. The research shows that the use of $15 \%$ Green Diesel blend with diesel fuel reduces $\mathrm{CO}_{2}$ emissions by $5 \%$, reduces hydrocarbon emissions and $\mathrm{CO}$ by $40 \%$ and also reduces noise emissions due to high cetane number.

Green Diesel is the first significant step towards more and more advanced solutions that meet or even exceed the strict Italian and European biofuel regulations. Italian legislation requires that as much as $10 \%$ of fuels sold in Italy should be produced from renewable raw materials, of which about $1.6 \%$ are to constitute the so-called advanced biofuels. Green Diesel fuel can be blended with conventional diesel in large proportions to power vehicles equipped with self-ignition engines. Due to the fact that it is obtained from the hydrogenation of vegetable oils, it does not contain 
oxygen and is a pure hydrocarbon, unlike traditional biodiesel. It should also be noted that the European Commission has established mandatory criteria for sustainable development for biocomponents that cover soil, water and air protection, ensuring socio-economic sustainability, while preventing competition from the food supply chain.

Green Diesel meets all these requirements, and thanks to the flexibility of its production process it can be obtained from waste animal fats or household waste oil, as well as from the so-called "advanced" sources such as suitable pretreated lignocellulose waste. Work is continuing on the implementation of future European directives in the field of the increasing use of advanced biofuels, which will definitely reduce the emissions of greenhouse gases and harmful compounds into the environment.

\section{Nomenclature}

$\begin{array}{llll}\text { CFPP } & \text { cold filter plugging point } & \text { LVHV } & \text { low value high volume } \\ \text { CI } & \text { compression ignition } & \text { LPG } & \text { liquid petroleum gas } \\ \text { EU } & \text { European Union } & \text { RED II } & \text { Renewable Energy Directive II } \\ \text { FAME } & \text { fatty acid methyl esthers } & \text { RES } & \text { renewable energy sources } \\ \text { GtL } & \text { gas to liquid } & \text { RME } & \text { rapeseed methyl esthers } \\ \text { HVLV } & \text { high value low volume } & \text { WtW } & \text { well to wheel } \\ \text { HVO } & \text { hydrotreated vegetable oil } & & \end{array}$

\section{Bibliography}

[1] Dyrektywa Parlamentu Europejskiego i Rady 2009/28/WE z dnia 23 kwietnia 2009 r. w sprawie promowania stosowania energii ze źródeł odnawialnych zmieniająca i w następstwie uchylająca dyrektywy 2001/77/WE oraz 2003/30/WE (Tekst mający znaczenie dla EOG).

[2] BIERNAT, K., MALINOWSKI, A., GNAT, M. The possibility of future biofuels production using waste carbon dioxide and solar energy. Chapter 5 in: Biofuels, Economy, Environment and Sustainability Edited by Zhen Fang, IntechOpen ISBN 978-953-51-0950-1, February 2013.

[3] BIERNAT, K. The possibility of creating biorefinery in Polish bioeconomy, stakeholder event on the bio-based industries public-private partnership. Warsaw, 22 November 2013.

[4] BIERNAT, K., GRZELAK, P.L. Biorefinery systems as an Element of Sustainable development. Biofuels - Status and Perspective. InTech, 2015. https://doi.org/10.5772/60448

[5] KLECAN, R. Paliwa do silników Diesla. Archiwum Gospodarki Odpadami i Ochrony Środowiska. 2006, 3, 55-68.

[6] SKRZYŃSKA, E., KMIEĆ, A., STANKIEWICZ, R. Oczyszczane oleje posmażalnicze jako surowiec do EMKT. Czasopismo Techniczne Technical Transactions. 2011, 10(108).

[7] Eni Refinery in Venice, 7.12.2016.

https://www.eni.com/docs/en_IT/enicom/operations/storiespeople/green-refinery/ENI-Raffineria-Eni-Venezia07.12.16.pdf

[8] BALDINI, L., FACCINI, S. Eni contribution to Energy Transition. New fuels for transportation and sustainable mobility, Facoltà di Ingegneria Civile e Industriale, Università La Sapienza, Roma, 19 Aprile 2018.

[9] Green Refinery: reinventing petroleum refineries, 23.05.2014.

https://www.eni.com/docs/en_IT/enicom/publicationsarchive/company/operations-strategies/refiningmarketing/eni_Green-Refinery_esecutivo.pdf

[10] MORANDI, P. Biodiesel vs Green Diesel, Cavalli Vapore, 18.12.2017

https://www.cavallivapore.it/2017/eni-diesel-piu-potenzadel-motore-e-piu-vita-alla-vostra-auto-grazie-alla-nuovatecnologia-ecofining/

[11] HILLAIRET, F. European renewable diesel and emerging feedstocks. The 8th Annual Jacobsen Conference - Forecasting Agriculture and biofuels interplay. Denver, May 2019.

\author{
Paulina Luiza Grzelak, M.A. - Motor Transport \\ Institute, Warsaw. \\ e-mail: paulina.grzelak@its.waw.pl
}

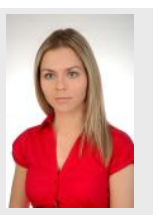

Andrzej Żółtowski, DEng. - Motor Transport Institute.

e-mail: andrzej.zoltowski@its.waw.pl 